\title{
PENGARUH MOVING CLASSSENTRA TERHADAP KEMANDIRIAN \\ ANAK USIA 4-5 TAHUN
}

\author{
Roudlotun Ni'mah, Farid Usman, Eva Khoirun nisa \\ IAI Sunan Giri Bojonegoro
}

\begin{abstract}
ABSTRAK
Kemandirian anak merupakan kemampuan anak untuk melakukan kegiatan dan tugas sehari-hari sendiri atau dengan sedikit bimbingan, sesuai dengan tahap perkembangan dan kemampuan anak.Pembelajaran di sekolah juga dapat mempengaruhi kemandirian seorang anak, bagaimana anak belajar mandiri, percaya diri, didapat dari sekolah.Penelitian ini diangkat atas dasar pemikiran yang menyatakan bahwa adanya pengaruh Moving Class, maka dapat meningkatkan kemandirian anak dalam menjalani kehidupan sehari-hari.Pada sisi inilah penulis mengkaji keberadaan pengaruh moving class di RA Islamiyah Ngasem terhadap kemandirian anak.Tujuan penelitian ini adalah untuk mengetahui tingkat dari masing-masing variabel serta untuk mengetahui pengaruh moving class terhadap kemandirian anak usia dini di RA Islamiyah Ngasem Kecamatan Ngasem.

Metodologi penelitian ini menggunakan kuantitatif dengan pendekatan deskritif. Analisa terhadap pengaruh moving class terhadap kemandirian anak usia 4-5 tahun RA Islamiyah Ngasem, penulis mencoba memaparkan semua data yang diperoleh dari berbagai literatur, wawancara langsung, kemudian data-data yang terkumpul dianalisa berpedoman pada sumber-sumber yang tertulis.

Berdasarkan hasil penelitian, diperoleh bahwa pengaruh moving class terhadap kemandirian anak mempunyai peranan yang sangat besar, karena moving class mampu membuat anak-anak lebih mandiri. Hasil yang dicapai dari pelaksanaan moving class ini bahwa dengan adanya moving class ini disambut positif oleh masyarakat, khususnya ibu-ibu guru dan anak didik, dan hasilnya bisa dilihat dari perilaku mereka sehari-hari yang mengalami evolusi.
\end{abstract}

Kata Kunci : Moving Class, Kemandirian Anak 


\section{A. Latar Belakang Masalah}

Manusia selalu dihadapkan pada situasi dan dinamika kehidupan yang terus berubah dan berkembang. Terlebih lagi ditunjang oleh laju perkembangan teknologi dan arus gelombang kehidupan global yang sulit atau tidak mungkin untuk dibendung.Sehingga tata nilai yang sudah mapan banyak diguncang oleh nilai - nilai baru yang belum tentu positif bagi kehidupan. Ketidakmandirian dan ketergantungan disiplin pada kontrol luar dan bukan dari niat sendiri yang ikhlas akan menghambat etos kerja dan etos kehidupan yang mapan. ${ }^{1}$

Problem di atas semakin meresahkan jika dikaitkan dengan situasi masa depan yang diperkirakan akan semakin kompleks dan penuh tantangan. Dan tantangan itu memberikan dua alternatif, yaitu pasrah pada nasib atau mempersiapkan diri sebaik mungkin.Oleh karena itu perkembangan kemandirian seseorang menuju ke arah kesempurnaan menjadi sangat penting untuk diupayakan lebih serius, sistematis dan terprogram.Salah satu hak dasar anak adalah hak untuk tumbuh dan berkembang.Artinya anak memperoleh kesempatan seluas-luasnya untuk tumbuh secara fisik dan berkembang secara psikologis. Ini semua akan terjadi bila lingkungan sangat kondusif sehingga memungkinkan perkembangan jiwa mereka dapat terlaksana dengan optimal. ${ }^{2}$

Beberapa ahli psikologi mengatakan, bahwa tahun pra sekolah merupakan tahap penting dalam perkembagan anak, karena pada masa itulah anak akan melalui tahapan usia pembentukan (pregang age), dimana struktur tingkah laku anak akan terbentuk. Anak juga akan melalui tahapan usia ingin tahu (exploratory age), yang memendam rasa ingin tahu begitu besar, anak pada usia ini juga melalui tahapan imitasi, yang sangat senang meniru segala hal yang dilihatnya. ${ }^{3}$ Pada anak-anak

\footnotetext{
${ }^{1}$ (kompasiana.com, diakses pada tanggal 18/03/2019).

${ }^{2}$ Agus Dariyo, Psikologi Perkembangan Anak Usia Tiga Tahun Pertama, (Bandung: Refika Aditama, 2007), h. 5.

${ }^{3}$ Dwi Lutfi Asrini, "Meningkatkan Kemampuan Berbahasa Melalui Metode Sentra Peran pada Anak Kelompok A RA Islamiyah Ngasem,”(Skripsi S1Universitas Ronggolawe Tuban, 2016), h. 2.
} 
yang telah diajar dan terlatih dengan baik oleh orang tua dirumah akan dapat melakukan kegiatan yang bertujuan untuk memenuhi kebutuhan diri sendiri dinamakan (self-help skill), sedangkan anak-anak yang tidak dilatih dengan baik oleh orang tua dirumah belum tentu dapat melakukan kegiatan yang bertujuan untuk memenuhi kebutuhan diri sendiri. ${ }^{4}$

Berdasarkan observasi yang dilakukan pada tanggal 23 Februari 2019 di RA Islamiyah Ngasem, penulis masih menemukan ada beberapa anak yang meminta ditemani di dalam kelas saat aktivitas belajar dan bermain di kelas, lalu masih ada juga yang menyerahkan tugas dari guru kepada orang tuanya saat belajar dan bermain di kelas. Masih ditemukannya beberapa anak yang masih sangat tergantung pada orang tua adalah seringnya ia menangis ketika ditinggal sebentar saja oleh ibunya. Untuk mendapat bantuan dari orang disekelilingnya, anak seringkali cengeng.

Kemandirian sangat penting di kembangkan pada anak sejak usia dini karena bekal kemandirian yang mereka dapatkan ketika kecil akan membentuk mereka menjadi pribadi yang mandiri, cerdas, kuat, dan percaya diri ketika menginjak dewasa nanti, sehingga mereka akan siap mengahadapi masa depan yang baik ${ }^{5}$.Mengembangkan perilaku kemandirian pada anak harus dimulai dari lingkungan rumah.Orangtua harus memberikan kesempatan kepada anak untuk melakukan segala sesuatu dengan sendiri tanpa perlu merasa kawatir kepada anaknya dengan memberikan sikap positif kepada anak dengan seperti memuji dan mendukung usaha mandiri di lakukan anak sebagai bentuk usaha mandiri dilakukannya.

\footnotetext{
${ }^{4}$ Agus Dariyo, Psikologi Perkembangan Anak Usia Tiga Tahun Pertama, (Bandung: Refika Aditama, 2007), h. 169-172

${ }^{5}$ Anissa Mardiana, "Hubungan Pelaksanaan Kemandirian Anak dalam Keluarga dengan Pelaksanaan Kemandirian Anak di Sekolah Kelompok A Paud Pertiwi 1 Kota Bengkulu,'(Skripsi S1 Universitas Bengkulu, 2014), h.
} 
Mengembangkan perilaku kemandirian tidak harus di lakukan dilingkungan rumah saja, tetapi dalam lingkungan sekolah perlu memberikan dukungan agar anak bisa mandiri dalam pengembangan perilaku kemandirian anak, guru hendaknya memperhatikan perkembangan pada diri anak, memilih metode dan kurikulum yang sesuai dengan tahap perkembangan anak untuk membantu guru dalam mengembangkan prilaku kemandirian pada $\operatorname{anak}^{6}$.Anak meskipun usianya masih sangat muda namun diharuskan memiliki pribadi yang mandiri.Alasan mengapa hal ini diperlukan karena ketika anak terjun ke lingkungan di luar rumah sudah tidak tergantung kepada orangtua. ${ }^{7}$

Kemandirian dalam arti psikologis dan mentalis mengandung pengertian keadaan seseorang dalam kehidupannya yang mampu memutuskan atau megerjakan sesuatu tanpa bantuan orang lain. Kemampuan demikian hanya mungkin dimiliki jika seseorang berkemampuan memikirkan dengan seksama tentang sesuatu yang dikerjakannya atau diputuskannya, baik dalam segi-segi negatif dan kerugian yang akan dialaminya. ${ }^{8}$

Kemandirian bertitik tolak pada paradigma yang menyatakan bahwa setiap individu atau kelompok bertanggung jawab atas kehidupannya sendiri. Stein dan Book menyatakan bahwa kemandirian merupakan kemampuan untuk mengarahkan dan mengendalikan diri sendiri dalam berpikir dan bertindak, serta tidak merasa bergantung pada orang lain secara emosional. ${ }^{9}$ Jika ditinjau dari perspektif psikologis, menurut Luther kemandirian pada dasarnya berawal dari adanya rasa

\footnotetext{
${ }^{6}$ Ibid.,

${ }^{7}$ Ibid.,

${ }^{8}$ Hasan Basri, Remaja Berkualitas Problematika Remaja dan Solusinya (Yogyakarta: Pustaka Pelajar, 1996), h. 53.

${ }^{9}$ Steven J. Stein and Howard E. Book, Ledakan EQ, Terjemahan Trinanda Rainy Januarsari dan Yudhi Murtanto (Bandung: Kaifa, 2000), h. 105.
} 
kemandirian diri (self-efficacy) atau persepsi seseorang tentang seberapa baik individu dapat menangani suatu masalah yang muncul. ${ }^{10}$

Kemandirian anak merupakan kemampuan anak untuk melakukan kegiatan dan tugas sehari-hari sendiri atau dengan sedikit bimbingan, sesuai dengan tahap perkembangan dan kemampuan anak. ${ }^{11}$ Definisi lain menurut Einon kemandirian anak usia dini ialah kemampuan anak untuk melakukan perawatan terhadap diri sendiri, seperti makan, berpakaian, ke toilet dan mandi. ${ }^{12}$ Kemandirian merupakan suatu sikap yang diperoleh secara kumulatif melalui proses yang dialami seseorang dalam perkembangannya. Dimana dalam proses menuju kemandirian, individu belajar untuk menghadapi berbagai situasi dalam ligkungannya sampai ia mampu berpikir dan mengambil tindakan yang baik dalam mengatasi setiap situasi. ${ }^{13}$

Ciri khas kemandirian pada anak diantaranya mereka memiliki kecenderungan dan kemampuan dalam memecahkan masalah dari pada berkutat dalam kekhawatiran bila terlibat masalah.Anak yang mandiri tidak takut dalam mengambil resiko karena sudah mempertimbangkan hasil sebelum berbuat.Anak yang mandiri percaya terhadap penilaian sendiri, sehingga tidak sedikit-sedikit bertanya atau meminta bantuan.Anak yang mandiri memiliki kontrol yang lebih baik terhadap kehidupannya. Covey menegaskan bahwa kemandirian memiliki ciriciri, diantarnya: (1) secara fisik mampu bekerja sendiri, (2) secara mental dapat berpikir sendiri, (3) secara kreatif mampu mengekspresikan gagasannya dengan cara yang mudah dipahami, dan (4) secara emosional kegiatan yang dilakukannya dipertanggungjawabkan sendiri. ${ }^{14}$

\footnotetext{
${ }^{10}$ Fred Luther, Organizational Behavior (New York: Mc. Grow-Hill International Edition, 1995), h. 115

${ }^{11}$ Abdul Majid, Pendidikan Karakter (Bandung: PT. Rosdakarya, 2012), h. 26.

${ }^{12}$ Dorothy Einon, Learning Early (Jakarta: Grasindo, 2006), h. 204.

${ }^{13}$ Zainun Mutadin, "Kemandirian sebagai Kebutuhan Psikologis pada Remaja”, E. Psikologi 2002, http://e-psikologi.com/ h.5.

${ }^{14}$ Steven R. Covey, The Seven Habits of Highly Effective People, terjemahan Budijanto (Jakarta: Binarupa Aksara, 1997), h. 38-39
} 
Kemandirian dalam konteks individu memiliki aspek yang lebih luas dari sekedar aspek fisik, yaitu: aspek emosi ditunjukkan dengan kemampuan mengontrol emosi, aspek ekonomi ditunjukkan dengan kemampuan mengatur ekonomi dan tidak tergantung kebutuhan ekonomi pada orang tua, aspek intelektual ditunjukkan dengan kemampuan mengatasi berbagai masalah yang dihadapi dan aspek sosial ditunjukkan dengan kemampuan berinteraksi dengan orang lain. ${ }^{15}$ Ada tiga aspek atau bentuk kemandirian anak usia dini yaitu: kemandirian fisik, kemandirian emosional dan kemandirian sosial.

Faktor-faktor yang mempengaruhi kemandirian dan membentuk kemandirian adalah: (1) Lingkungan. Lingkungan keluarga (internal) dan masyarakat (eksternal) akan membentuk kepribadian seseorang termasuk kemandirian (2) Pola Asuh. Peran dan pola asuh orang tua sangat berpengaruh dalam penanaman nilai-nilai kemandirian seorang anak (3) Pendidikan.Pendidikan memiliki sumbangan yang berarti dalam perkembangan terbentuknya kemandirian pada diri seseorang yakni (1) Interaksi social. Interaksi sosial melatih anak menyesuaikan diri dan bertanggungjawab atas apa yang dilakukan sehingga diharapkan anak mampu menyelesaikan masalah yang dihadapi (2) Intelegensi. Intelegensi merupakan faktor penting yang berpengaruh terhadap proses penentuan sikap, pengambilan keputusan, penyelesaian masalah serta penyesuaian $\operatorname{diri}^{16}$.

Salah satu pendidikan anak usia dini yang mengembangkan perkembangan anak yang melatih perkembangan sosial emosional dan kognitifnya adalah dengan menggunakan BCCT (Beyond Centre ang Circle Time). BCCT (Beyond Centre and Circle Time) atau yang biasa disebut dengan senling (sentra dan lingkaran) ialah metode yang digunakan untuk melatih perkembangan anak dengan menggunakan metode bemain ${ }^{17}$.Pembelajarannya berpusat di sentra main dan saat anak dalam lingkaran. Sentra main adalah zona atau area main anak yang dilengkapi

\footnotetext{
${ }^{15}$ Zainun Mutadin, "Kemandirian sebagai Kebutuhan Psikologis pada Remaja", h.5

${ }^{16}$ John W. Santrock, Adolesence Perkembangan Remaja (Jakarta: Erlangga, 2003), h. 145-220.

${ }^{17}$ Melalui Sentra dan Saat Lingkaran. (Depdiknas.2005)
} 
seperangkat alat main yang berfungsi sebagai pijakan lingkungan yang diperlukan untuk mendukung perkembangan anak dalam tiga jenis permainan, yakni main Sensorimotor (fungsional), main peran dan main pembangunan. Sedangkan saat lingkaran adalah saat pendidik duduk bersama anak dengan posisi melingkar untuk memberi pijakan pada anak yang dilakukan sebelum dan sesudah main.Pada metode $B C C T$ ini anak diharuskan memilih dan melakukan kegiatan pembelajaran dengan mandiri. Ada tujuh sentra yang dikembangkan oleh Dr. Pamela Phelps, yaitu sentra persiapan, senta balok, sentra peran besar, sentra peran kecil, sentra bahan alam, sentra seni dan sentra music ${ }^{18}$.

Pada model sentra ini dapat dilakukan dengan menggunakan sistem moving class yaitu pembelajaran yang bercirikan siswa berpindah dari kelas yang satu ke kelas yang lain sesuai dengan jadwal pelajaran pada setiap pergantian jam pelajaran. Di dalam penerapan moving class terdapat unsur pengelolaan kelas yang dilakukan oleh masing-masing guru pelajaran guna memfasilitasi siswa terhadap mata pelajaran yang bersangkutan. Untuk di lembaga PAUD moving class yang diterapkan adalah moving class sentra dimana nanti anak setiap harinya akan berpindah kelas sentra sesuai jadwal yang telah ditentukan. Manfaat penerapan pembelajaran moving class ini, dimaksudkan agar memperoleh waktu belajar yang optimal, memupuk kedisiplinan peserta didik, dan kemandirian pada diri peserta didik. Jadi, kemandirian sangat diperlukan ketika anak akan berpindah kelas ia membawa barang-barang yang diperlukannya dengan sendiri.

Kemandirian anak usia dini memang menjadi alasan bagi para orang tua dan pendidik untuk mempertimbangkan proses pendidikan anak pada usia prasekolah. Kenyataannya saat ini masih banyak anak usia prasekolah yang belum memiliki kemandirian dalam melakukan kegiatan disekolah. Begitu pula yang terjadi pada di RA Islamiyah Ngasem, dimana masih ada anak yang meminta ditemani didalam kelas saat aktivitas belajar dan bermain dikelas, lalu masih ada

\footnotetext{
${ }^{18}$ Mukhtar Latif, dkk. Orientasi Baru Pendidikan Anak Usia Dini Teori dan Aplikasi.(Jakarta : Prenamedia Group, 2013), h. 124.
} 
juga yang menyerahkan tugas dari guru kepada orang tuanya saat belajar dan bermain dikelas. Masih ditemukannya siswa yang masih sangat tergantung pada orang tua adalah seringnya ia menangis ketika ditinggal sebentar saja oleh ibunya. Untuk mendapat bantuan dari orang disekelilingnya, anak seringkali cengeng.Kecengengan ini bahkan bisa terbawa hingga masa akhir masa prasekolah dan menjadi anak rewel, merengek serta sering melontarkan protes bila menemui hal-hal yang tidak sesuai dengan keinginannya.

Berdasarkan pertimbangan-pertimbangan tersebut serta melihat permasalahan di RA Islaimyah Ngasem maka penulis ingin mengangkat masalahmasalah tersebut ke dalam skripsi dengan judul: "Pengaruh Moving Class Terhadap Kemandirian Anak Usia 4-5 Tahun RA Islamiyah Ngasem”

\section{B. Rumusan Masalah}

Berdasarkan latar belakang di atas, maka permasalahan yang diangkat dalam penelitian ini adalah:

1. Bagaimana penggunaan moving class pada anak usia 4-5 tahun di RA Islamiyah Ngasem Kecamatan Ngasem Kabupaten Bojonegoro

2. Bagaimana kemandirian anak usia 4-5 tahun di RA Islamiyah Ngasem Kecamatan Ngasem Kabupaten Bojonegoro

3. Adakah pengaruh penggunaan moving class terhadap kemandirian anak usia 4-5 tahun di RA Islamiyah Ngasem Kecamatan Ngasem Kabupaten Bojonegoro?

\section{Hipotesis Penelitian}

1. Hipotesis Kerja/alternative $\left(\mathrm{H}_{\mathrm{a}}\right)$ :

Hipotesis kerja yang diajukan berbunyi: "Bahwa ada pengaruh moving class terhadap kemandirian anak usia 4-5 tahun di RA Islamiyah Ngasem” 
2. Hipotesis Nihil $\left(\mathrm{H}_{0}\right)$ :

Hipotesis nihil yang diajukan berarti : "Bahwa tidak ada pengaruh moving class terhadap kemandirian anak usia 4-5 tahun di RA Islamiyah Ngasem".

\section{Pengolahan Data}

Analisis data ini dimaksudkan untuk mengetahui ada dan tidaknya pengaruh Moving class ( Variabel X) terhadap kemandirian anak (Variabel Y) RA Islamiyah Ngasem dengan menggunakan korelasi Product Moment, dengan langkah sebagai berikut:

a. Data yang dibutuhkan

1) Hasil mengikuti moving class

2) Kemandirian anak

b. Hipotesis kerja $\left(\mathrm{H}_{\mathrm{a}}\right)$

Hipotesis kerja diajukan adalah "Bahwamoving classberpengaruh Terhadap Kemandirian Anak Usia 4-5 Tahun RA Islamiyah Ngasem"

c. Hipotesis nihil $\left(\mathrm{H}_{0}\right)$

Hipotesis nihil diajukan adalah "Bahwa moving classtidakberpengaruh Terhadap Kemandirian Anak Usia 4-5 Tahun RA Islamiyah Ngasem”

d. Teknik analisis data

Teknik analisi data yang digunakan adalah analisis Product Moment dengan rumus sebagai berikut:

$r_{x y}=\frac{N \Sigma X Y-(\Sigma X)(\Sigma Y)}{\sqrt{ }\left\{N \Sigma X^{2}-(\Sigma X)^{2}\right\}\left\{N \Sigma Y^{2}-(\Sigma Y)^{2}\right\}}$ 
e. Kaidah hipotesis

Kaidah uji hipotesis penelitian adalah:

1) Ditolak $\mathrm{H}_{0}$ jika $r$ hasil $\left(\mathrm{r}_{\mathrm{xy}}\right)>\mathrm{r}$ tabel $\left(\mathrm{r}_{\mathrm{t}}\right)$

2) Diterima $\mathrm{H}_{0}$ jika $r$ hasil $\left(\mathrm{r}_{\mathrm{xy}}\right)<\mathrm{r}$ tabel $\left(\mathrm{r}_{\mathrm{t}}\right)$

Berdasarkan rumus analisis korelasi Product Moment maka dapatdimasukkan perhitungan dengan melihat tabel sebagai berikut:

Tabel 4.6 Korelasi Product Moment antara Moving Class dan Kemandirian Anak

\begin{tabular}{|c|c|c|c|c|c|}
\hline $\mathbf{N o}$ & $\mathbf{X}$ & $\mathbf{Y}$ & $\mathbf{X 2}$ & $\mathbf{Y 2}$ & $\mathbf{X Y}$ \\
\hline $\mathbf{1}$ & 33 & 35 & 1089 & 1225 & 1155 \\
\hline $\mathbf{2}$ & 32 & 33 & 1024 & 1089 & 1056 \\
\hline $\mathbf{3}$ & 36 & 33 & 1296 & 1089 & 1188 \\
\hline $\mathbf{4}$ & 30 & 33 & 900 & 1089 & 990 \\
\hline $\mathbf{5}$ & 22 & 28 & 484 & 784 & 616 \\
\hline $\mathbf{6}$ & 30 & 29 & 900 & 841 & 870 \\
\hline $\mathbf{7}$ & 36 & 33 & 1296 & 1089 & 1188 \\
\hline $\mathbf{8}$ & 28 & 30 & 784 & 900 & 840 \\
\hline $\mathbf{9}$ & 30 & 33 & 900 & 1089 & 990 \\
\hline $\mathbf{1 0}$ & 35 & 34 & 125 & 1156 & 1190 \\
\hline $\mathbf{1 1}$ & 35 & 37 & 1225 & 1369 & 1295 \\
\hline $\mathbf{1 2}$ & 33 & 32 & 1089 & 1024 & 1056 \\
\hline $\mathbf{1 3}$ & 38 & 30 & 1444 & 900 & 1140 \\
\hline $\mathbf{1 4}$ & 20 & 25 & 400 & 625 & 500 \\
\hline $\mathbf{1 5}$ & 30 & 28 & 900 & 784 & 840 \\
\hline $\mathbf{1 6}$ & 30 & 28 & 900 & 784 & 840 \\
\hline $\mathbf{1 7}$ & 32 & 32 & 1024 & 1024 & 1024 \\
\hline $\mathbf{1 8}$ & 34 & 37 & 1156 & 1369 & 1258 \\
\hline $\mathbf{1 9}$ & 35 & 34 & 1225 & 1156 & 1190 \\
\hline & & & & & \\
\hline
\end{tabular}




\begin{tabular}{|c|c|c|c|c|c|}
\hline $\mathbf{2 0}$ & 34 & 29 & 1156 & 841 & 986 \\
\hline $\mathbf{2 1}$ & 38 & 35 & 1444 & 1225 & 1330 \\
\hline $\mathbf{2 2}$ & 30 & 30 & 900 & 900 & 900 \\
\hline $\mathbf{2 3}$ & 32 & 30 & 1024 & 900 & 960 \\
\hline $\mathbf{2 4}$ & 36 & 32 & 1296 & 1024 & 1152 \\
\hline $\mathbf{2 5}$ & 30 & 30 & 900 & 900 & 900 \\
\hline $\mathbf{2 6}$ & 33 & 35 & 1089 & 1225 & 1155 \\
\hline $\mathbf{2 7}$ & 30 & 32 & 900 & 1024 & 960 \\
\hline $\mathbf{2 8}$ & 34 & 35 & 1156 & 1225 & 1190 \\
\hline $\mathbf{2 9}$ & 30 & 33 & 900 & 1089 & 990 \\
\hline $\mathbf{3 0}$ & 35 & 33 & 1225 & 1089 & 1155 \\
\hline $\mathbf{N}=\mathbf{3 0}$ & $\mathbf{\Sigma X}=\mathbf{9 6 1}$ & $\mathbf{\Sigma Y = 9 5 8}$ & $\mathbf{\Sigma}^{\mathbf{X}}=\mathbf{3 1 2 5 1}$ & $\mathbf{\Sigma} \mathbf{Y}^{\mathbf{2}}=\mathbf{3 0 8 2 8}$ & $\mathbf{\Sigma X Y}=\mathbf{3 0 9 0 4}$ \\
\hline
\end{tabular}

Dengan melihat tabel kerja di atas ,maka dapat diketahui:

$$
\begin{array}{ll}
\mathrm{N} & =30 \\
\Sigma \mathrm{X} & =961 \\
\Sigma \mathrm{Y} & =958 \\
\Sigma \mathrm{X}^{2} & =31251 \\
\Sigma \mathrm{Y}^{2} & =30828 \\
\Sigma \mathrm{XY} & =30904
\end{array}
$$

Langkah selanjutnya adalah hasil tabel tersebut dimasukkan dalam rumus korelasi product moment sebagai berikut:

$$
\begin{aligned}
& \mathrm{r}_{\mathrm{xy}}=\frac{\mathrm{N} \Sigma \mathrm{XY}-(\Sigma \mathrm{X})(\Sigma \mathrm{Y})}{\sqrt{ }\left\{\mathrm{N} \Sigma \mathrm{X}^{2}-(\Sigma \mathrm{X})^{2}\right\}\left\{\mathrm{N} \Sigma \mathrm{Y}^{2}-(\Sigma \mathrm{Y})^{2}\right\}} \\
& \mathrm{r}_{\mathrm{xy}}=\frac{30 \times 30904-961 \times 958}{\sqrt{ }\left\{30 \times 31251-(961)^{2}\right\}\left\{30 \times 30828-(958)^{2}\right\}} \\
& \mathrm{r}_{\mathrm{xy}}=\frac{927120-920638}{\sqrt{ }\{937530-92521\}\{924840-917764\}}
\end{aligned}
$$




$$
\begin{aligned}
& r_{x y}=\frac{6482}{\sqrt{ } 14009 \times 7076} \\
& r_{x y}=\frac{6482}{\sqrt{99,127684}} \\
& r_{x y}=\frac{6482}{9956,289} \\
& r_{x y=0,651}
\end{aligned}
$$

Telah diketahui bahwa $\mathbf{r}_{\mathbf{0}}=0,651$ dengan $\mathbf{N}=30$ dan pada taraf signifikansi $5 \% \mathbf{r}_{\mathbf{t}}=$ 0,361 dan pada taraf signifikansi $1 \% \mathbf{r}_{\mathbf{t}}=0,463$.

\section{E. Pembahasan}

a. Moving class

Data untuk mengetahui tentang moving class pada anak usia 4-5 tahunsemester II tahun ajaran2018/2019dalamhalpartisipasi mengikuti moving classdiperoleh daritesyangterdiri dari10butirsoalyang telahdiujivaliditasdanreliabilitasnya. Kemungkinannilai tertinggiyang diperolehsiswaadalah38sedangkankemungkinannilaiterendah adalah 20 . Nilai yang diperoleh dari moving class, kemudian dikategorikanke dalamlimakategori. MenurutZainalArifinpengkategorian tersebutyaitu ${ }^{19}$ :
1) Mean $+1,5$ (standar deviasi)
$\longrightarrow$ (sangat baik)
2) Mean $+0,5$ (standar deviasi)

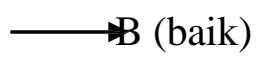
3) Mean $-0,5$ (standar deviasi)
$\longrightarrow$ (cukup)
4) Mean -1,5 (standar deviasi)
$\longrightarrow$ (kurang)
5) Kurangdari perhitungannilai $D$
$\longrightarrow$ (kurang sekali)

\footnotetext{
${ }^{19}$ Zainal Arifin, Penenlitian PendidikanMetode dan Paradigma Baru, Bandung: Remaja Rosda Karya, 2012. h. 236.
} 
Adapun hasil dari perhitungan kategori nilai moving class pada anak usia 4-5 tahun RA Islamiyah Ngasem,dapat disajikanke dalamtabeldistribusi frekuensi berikut ini.

Tabel4.7 DistribusiFrekuensiNilaiMoving Class RA Islamiyah Ngasem

\begin{tabular}{|c|l|c|c|c|l|}
\hline No & Nilai & Frekuensi & Persentase & $\begin{array}{c}\text { Cumulative } \\
\text { Persen }\end{array}$ & \multicolumn{1}{|c|}{ Kategori } \\
\hline 1. & $36-38$ & 5 & 8,24 & 8.24 & Sangat baik \\
\hline 2. & $35-33$ & 11 & 20,00 & 28.24 & Baik \\
\hline 3. & $28-30$ & 10 & 48,24 & 76.48 & Cukup \\
\hline 4. & $26-28$ & 3 & 18,82 & 95.30 & Kurang \\
\hline 5. & $<25$ & 1 & 4,71 & 100.01 & Kurangsekali \\
\hline & Jumlah & 85 & 100.00 & & \\
\hline
\end{tabular}

Berdasarkan tabel distribusi frekuensi nilai moving class, diketahuiada5orang siswa termasuk kategori A (sangat baik), 11orang siswa termasuk kategori B (baik), 10 orang siswa termasuk kategori C (cukup), 3 orang siswa termasuk kategori D (kurang), dan 1 orang siswa termasuk kategori E (kurang sekali). Mean nilai moving class tersebut apabila dimasukkan ke dalam kategori pada tabel di atas, maka nilai moving class pada siswa RA Islamiyah $\mathrm{Ngasem}$ termasuk kategori cukup.

b. Kemandirian Anak

Data untuk mengetahui tentang nilai kemandirian pada anak usia 45 tahun semester II tahun ajaran 2018/2019 dalam hal kemandirian anak diperoleh dari tes yang terdiri dari 10 butir soal yang telah diuji validitas dan reliabilitasnya. Kemungkinan nilai tertinggi yang diperoleh siswa adalah 37 sedangkan kemungkinan nilai terendah adalah 28. Nilai yang 
diperoleh dari kemandirian, kemudian dikategorikan ke dalam lima kategori. Menurut Zainal Arifin pengkategorian tersebut yaitu ${ }^{20}$ :

1) Mean $+1,5$ (standar deviasi)

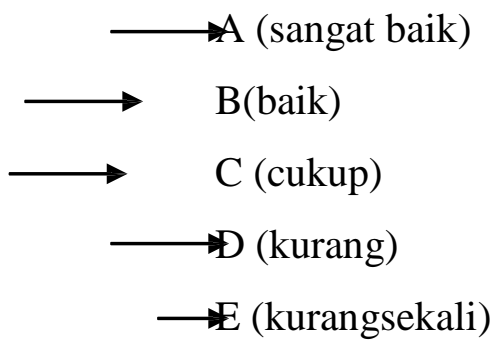

Adapun hasil dari perhitungan kategori nilai kemandirian pada anak usia 4-5 tahun RA Islamiyah Ngasem,dapat disajikan ke dalam tabel distribusi frekuensi berikut ini.

Tabel4.8 Distribusi Frekuensi Nilai Kemandirian RA Islamiyah Ngasem

\begin{tabular}{|c|l|c|c|c|l|}
\hline No & Nilai & Frekuensi & Persentase & $\begin{array}{c}\text { Cumulative } \\
\text { Persen }\end{array}$ & \multicolumn{1}{|c|}{ Kategori } \\
\hline 1. & $35-37$ & 5 & 8,24 & 8.24 & Sangat baik \\
\hline 2. & $31-33$ & 11 & 20,00 & 28.24 & Baik \\
\hline 3. & $29-30$ & 10 & 48,24 & 76.48 & Cukup \\
\hline 4. & $27-28$ & 3 & 18,82 & 95.30 & Kurang \\
\hline 5. & $<25$ & 1 & 4,71 & 100.01 & Kurangsekali \\
\hline & Jumlah & 85 & 100.00 & & \\
\hline
\end{tabular}

Berdasarkan tabel distribusi frekuensi nilai moving class, diketahui ada 5 orang siswa termasuk kategoriA (sangatbaik),11 orang siswa termasuk kategori B (baik), 10orang siswa termasuk kategori C (cukup), 3orang siswa termasuk kategori D (kurang), dan 1 orang siswa termasuk kategori E (kurang sekali). Mean nilai kemandirian tersebut

${ }^{20}$ Zainal Arifin, Penenlitian PendidikanMetode dan Paradigma Baru, Bandung: Remaja Rosda Karya, 2012. h. 236. 
apabila dimasukkan ke dalam kategori pada tabel diatas, maka nilai kemandirian pada siswa RA Islamiyah Ngasem termasuk kategori cukup.

c. Pengaruh moving class terhadap kemandirian

Adapun hipotesis yang peneliti ajukan dalam penelitian ini adalah "Adakah pengaruh yang signifikan dari Moving Class terhadap Kemandirian Anak RA Islamiyah Ngasem Kecamatan Ngasem Kabupaten Bojonegoro, diketahui:

$$
\begin{array}{ll}
r_{\mathrm{o}} & : 0,651 \\
\mathrm{r}_{\mathrm{t}} & : 0,361 \text { (signifikansi 5\%) } \\
0,463 & \text { (signifikansi 1\%) }
\end{array}
$$

Perbandingan antara $r_{o}$ dengan $r_{t} 5 \%=0,651>0,361, r_{o}$ dengan $r_{t} 1 \%$ $0,872>0,463$.

Dengan demikian dapat disimpulkan bahwa hipotesis alternative $\left(\mathrm{H}_{\mathrm{a}}\right)$ diterima dan hipotesis nihil $\left(\mathrm{H}_{0}\right)$ ditolak.Dengan kata lain bahwa ada pengaruh terhadap Moving Class terhadap Kemandirian Anak Usia 4-5 Tahun RA Islamiyah Ngasem Kecamatan Ngasem Kabupaten Bojonegoro.

\section{F. Kesimpulan}

Untuk memberikan gambaran tentang pokok-pokok bahasan dalam skripsi ini, maka dari uraian yang terdahulu baik yang bersifat teoritis maupun empiris dapat disimpulkan sebagai berikut:

1. Bahwa pembelajaran yang digunakan di RA Islamiyah menggunakan moving class.

2. Bahwa berdasarkan hasil angket bahwa kemandirian anak RA Islamiyah Ngasem baik hal ini dibuktikan mean variabel Y adalah 31,93. Hal ini di tunjukkan dengan interpretasi hasil rata-rata (mean) berada antara 30,00 s/d 39,99 . 
3. Bahwa kegiatan moving class memiliki hubungan dengan kemandirian anak usia 4-5 tahun RA Islamiyah Ngasem Kecamatan Ngasem Kabupaten Bojonegoro, hal ini dibuktikan dari perhitungan korelasi prodact moment di atas, ternyata hasil $r_{0}=0,651>r_{t} \quad$ dengan taraf signifikasi $5 \%=0,361$, Dan $r_{\mathrm{o}}=0,651>\mathrm{r}_{\mathrm{t}}$ dengan taraf signifikasi $1 \%=0,463$. Sebagai konsekwensinya hipotesis kerja $\left(\mathrm{H}_{\mathrm{a}}\right)$ diterima dan hipotesis nihil $\left(\mathrm{H}_{0}\right)$ ditolak. Dengan demikian dapat disimpulkan bahwa terdapat korelasi antaraMoving Class terhadap Kemandirian anak Usia 4-5 Tahun RA Islamiyah Ngasem Kecamatan Ngasem Kabupaten Bojonegoro',

\section{G. DAFTAR PUSTAKA}

Anwar, Saifudin.2001. Metode Penelitian. Pustaka Belajar. Yogyakarta.

Arikunto, Suharsimi. 2013. Prosedur Penelitian Suatu Pendekatan Praktik. Rineka Cipta. Jakarta.

Asrini,Dwi, Lutfi. 2016. Meningkatkan kemampuan berbahasa melalui metode sentra peran pada anak kelompok A RA Islamiyah Ngasem. Skripsi tidak diterbitkan.Program Pascasarjana. Bojonegoro.

Basri, Hasan. 1996. Remaja Berkualitas Problematika Remaja dan Solusinya.Pustaka Pelajar. Yogyakarta.

Dariyo.Agus.2005. PsikologiPerkembangan Anak 3 Tahun Pertama.PT Refika Aditama. Bandung.

Darmadi, Hamid. 2011. Metode Penelitian Pendidikan. Alfabeta. Bandung.

Depdiknas.2005. Melalui Sentra dan Saat Lingkaran.

Hadidan, Haryono Amirul.1998. Metodologi Pendidikan Islam.PustakaSetia. Bandung.

John. W. Santrock. 1995. Life Span Development. Erlangga. Jakarta.

Kemandirian Anak Usia 5-6 Tahun di Komunitas Pemulung. Jurnal Ilmiah VISI PPTK PAUDNI-VOL. 11, No. 1, Juni 2016 
Majid, Abdul. 2012. Pendidikan Karakter. PT. Rosdakarya. Bandung.

Mansur. 2005. Pendidikan Anak Usia Dini Dalam Islam. Pustaka Belajar. Yogyakarta.

Marion Dowling. 2005. Young Childern's Persona, Social and Emotional Development, Second Edition .Paul Chapman Publishing. London.

Mukhtar Latif, dkk. 2013. Orientasi Baru Pendidikan Anak Usia Dini Teori dan Aplikasi. Prenamedia Group. Jakarta.

Pengaruh Model Pembelajaran Beyond Centers And Circels Times (BCCT) dan

Kemandirian Terhadap Kreativitas. Jurnal Pendidikan Usia Dini PAUD PPs Universitas Negeri Jakarta.

Steven J. Stein and Howard E. Book. 2000. Ledakan EQ, Terjemahan Trinanda

Rainy Januarsary dan Yudi Murtanto. Kaifa. Bandung.

Steven R Covey. 1997. The Seven Habits of Highly Effective People, Terjemahan Budianto. Binarupa Aksara. Jakarta.

Sudjiono, Anas. 2004. Pengantar Statistik Pendidikan. Rajawali Pres. Jakarta.

Sugiyono. 2014. Metode Penelitian Kualitatif Kuantitatif dan R\&D.Alfabeta. Bandung.

Syaiful Sagala. 2009. Kemampuan Profesional Guru Dan Tenaga Kependidikan.Alfabeta. Bandung.

Undang-Undang RI No.20 Tahun 2003 tentang Sistem Pendidikan Nasional .Pustaka Widyatama. Yogyakarta.

Wismiarti.2012. Sentra, Modul PPOT 7. Penerbit Sekolah Al-Falah. Jakarta Timur. Wiyani, NovanArdy. 2013.Bina KarakterAnak Usia Dini. Ar-ruzz Media. Yogyakarta.

Yamin,Martinisdkk.2013.PanduanPendidikanAnakUsiaDini(PAUD). Referensi (GaungPersadapers Group). Jakarta.

Zainun Mutadin, “Kemandirian Sebagai Kebutuhan Psikologis pada Remaja”. 